\title{
International Legal Relations Regulation in the Field of Cooperation between Law Enforcement (Police) Authorities
}

\author{
Demian V. Smernytskyi, Vitalii P. Bakal, Mykola P. Budzynskyi, Yevhen V. Samus, Maryna V. \\ Tryhubenko
}

\begin{abstract}
The article is devoted to problems of international legal relations regulation in the field of cooperation between law enforcement authorities. The principal focus is laid particularly on police cooperation that gives the edge in countering the current challenges to national and global security. The meaning of such cooperation as an object of international legal regulation is given a thorough analysis. The main perspectives of implementing the international police cooperation are determined in view of the existing threats to the security environment as well as by taking into account the transboundary nature of criminal behavior. The process structure of the international legal relations regulation in the sphere of police cooperation is addressed. It is shown that such regulation is based on the needs of the countries' national security, but with due regard to national legislation. The latter settles two problems outright: preventing the restriction of national sovereignty and ensuring maximum legality in the criminal prosecution process. The character and emphasis of international legal relations regulation in the sphere of police cooperation were determined. It is emphasized that such regulation includes separate methods of international, administrative and criminal procedural law. Thus, it is concluded that the development of a separate branch of law is a prerequisite, especially in the legal doctrine of international police law. This will ensure the effectiveness and efficiency of international law in the national legal system.
\end{abstract}

Index Terms: International legal regulation, police cooperation, Interpol, Europol, state regulation.

\section{INTRODUCTION}

Globalization in socio-economic and socio-political processes implies the expansion onto the new levels of intergovernmental cooperation and collaboration. It is not only economic relations that require coordination as the market is self-regulated, but democratic principles of building a society involve expanding the boundaries of free operation and reducing the administrative pressure from the state. But the importance of coordination is undeniable as

Revised Manuscript Received on October 30, 2019.

* Correspondence Author

Demian V. Smernytskyi*, State Research Institute of the Ministry of Internal Affairs of Ukraine, Kyiv, Ukraine.

Vitalii P. Bakal, State Research Institute of the Ministry of Internal Affairs of Ukraine, Kyiv, Ukraine.

Mykola P. Budzynskyi, State Research Institute of the Ministry of Internal Affairs of Ukraine, Kyiv, Ukraine.

Yevhen V. Samus, State Research Institute of the Ministry of Internal Affairs of Ukraine, Kyiv, Ukraine.

Maryna V. Tryhubenko, State Research Institute of the Ministry of Internal Affairs of Ukraine, Kyiv, Ukraine.

(c) The Authors. Published by Blue Eyes Intelligence Engineering and Sciences Publication (BEIESP). This is an open access article under the CC BY-NC-ND license (http://creativecommons.org/licenses/by-nc-nd/4.0/) regards the legality observance and steadiness of socio-economic relations development. Reducing the quantity and rigidity of permitting procedures and state regulation, expanding the international trade opportunities and the movement of goods and services, finance and labor resources - all of the above have one important negative risk - the transnationalization of crime. Currently most criminal structures and groups use modern technologies and methods of committing crimes that are almost entirely digitalized, and the nature of the criminal structures interaction has almost completely transformed into a virtual one. On the one hand, this factor complicates the work of the law enforcement authorities, but on the other - it puts into force their cooperation at the interstate, regional and global levels. At present police cooperation is one of the key forms of international activity, and the fact that national security of many countries depends on its quality and efficiency actualizes the evolution intensification of international legal regulation of this international relations sector. Authors in [1] claim that the academic interest in transnational activities of the police began to emerge only in the late 1980s, and this gave a powerful high-grade impetus to enhance such cooperation. First, it has bureaucratized police cooperation to a certain extent; and, second, has created the necessary methodological basis for the implementation of cooperation [1]. In [2], elaborating the problem of intensifying the international police cooperation, researchers actively promote the need for the institutionalization of such cooperation. According to [3], such institutionalization should not only take place within Interpol, because in view of the development and transformation of international forms of crime, police cooperation requires a more contact interaction, even the execution of the joint police operations. In the opinion of [4], [5], such intensification and the need to reconfigure the forms of cooperation require globalization and unification of the process of transnational police personnel training, as well as conducting transnational police training as an element of cooperation between countries in the global security framework. The same conclusion was drawn in [6], which was based on more than 150 years of experience in international cooperation in the field of coordinating police operations. The researcher actually arrives at the conclusion about the need to intensify and develop new forms of police co-operation [6]. We share the point of view of these researchers to the full extent, however we suggest that attention should be paid to the presence of certain risks in this context, in particular, that the further globalization of police cooperation undermines the notion of state sovereignty. 
The center stage of control and legality of international cooperation and the activities of the police agencies of other states on the territory of a particular country is being shifted towards internationalization. In other words, a gradual transition from internal to external security controls from the national government to international police agencies or organizations is underway.

Author in [7] explains this by the emergence of new forms of crime that can not be overcome within a single country, and the lack of cooperation between the police authorities of different countries will make it eventually impossible to handle the problem of spreading such crime. What is involved here is in particular terrorism, Islamic fundamentalism and religious extremism. Authors in [8] also support the standpoint, that dealing with the problems of extremism and terrorism spread is impossible due to national legislation and the operation of the national police. If we address the nature of international police cooperation, it can be seen that it refers to the interaction of several police actors of different national subordination in order to exchange intelligence, conduct investigations and detain suspects. One can even state that international police cooperation is the driving force through which anticriminal intelligence advances through national and geopolitical borders in order to overcome and prevent criminal effects. In this connection, in [9] emphasizes the need for regionalization and globalization of police cooperation. As in [10] points out, international cooperation is in fact the only opportunity to overcome and prevent global crime, such as terrorism. Researcher [11] substantiates the agenda of antiterrorist activity and the need for international cooperation in the field of overcoming it, but the researcher exemplifies this on particular cities, which imparts a practical significance to his conclusions. Authors in [12] note, that global criminal activity is constantly transforming, acquiring the features which on the one hand decriminalize it, and on the other hand, further undermine socio-political and socio-economic processes. Therefore, recently the issue of information exchange intensification between the police agencies of different countries is being updated in the scientific community. Such a point of view, in particular, is supported in [13]-[15]. Scientists in [16] developing this thesis, draw attention to the need to elaborate new mechanisms for international legal regulation of police cooperation, which in particular would encompass the Internet and digital crime. This above standpoint is also supported by [17].

However, there is an area of research that examines the need for optimization and harmonization of international legal and regional regulation of police cooperation to overcome such manifestations of international crime as cyberterrorism and global financial fraud against the legalization of assets acquired by crime. In particular, this is stated by [18]. Globalization and digitalization of police cooperation are necessary, since it makes possible, among other things, to provide the legal status of evidence for the information collected abroad or by the other countries' police. This information enables to identify a specific offender and identify specific criminal groups. The information exchange provides opportunities for developing strategies for combating crime and identifying the resources necessary for carrying out the complex operations that often require the formation of international police teams [19]. Thus, we conclude that there is a number of well-established points of view that can be presented as hypotheses of scientific research: first, the current state of international legal regulation of police cooperation needs to be improved with an emphasis on strengthening international collaboration; and second, there is a steady need for internationalization of such cooperation in order to effectively combat international crime, and in particular such forms as extremism and terrorism. There is another hypothesis though, that requires the transformation of modern international legal regulation of police cooperation, shifting the emphasis onto the regional level with enhanced opportunities for police operations on the territories of other countries.

Taking into consideration all of the above, it seems expedient to formulate such research objectives as defining the present-day character and deficiencies of the international legal regulation of international police cooperation and suggesting the ways to eliminate them by expanding the potential of regional police cooperation by way of applying more specific forms than the information exchange.

\section{MATERIALS AND METHODS}

An extensive system of international acts regulating relations in the field of cooperation between police authorities is laid at the basis of the study, in addition to the array of modern researchers' works on the identified issues.

In particular, the Convention adopted pursuant to Article 3 of the European Community Treaty establishing the European Police Office (Europol Convention) [20] is studied; General principles for the organization of the International Criminal Police (Interpol) [21]; the Interpol Constitution of 1956 [22]; Council Decision 2008/615/JHA on enhancing the cross-border cooperation, in particular in countering terrorism and cross-border crime dated June 23, 2008 [23]; Council Decision C 2008/616/JHA on the implementation of Decision 2008/615/JHA on advancing the cross-border cooperation, particularly in battling terrorism and cross-border crime dated June 23, 2008 [24]; Recommendation No. R (87)15 of the Committee of Ministers to member states regulating the use of personal data in the police sector [25].

A special attention is also paid to international legal acts in the field of regulation of the information and analytical aspect of international police cooperation. In particular, it examines the Council Decision No. 2007/533/JHA on the establishment, operation and use of the second generation Schengen Information System (SIS II) dated June 12, 2007 [26]; Regulation (EC) No. 1986/2006 on the access to the second generation Schengen Information System (SIS II) by the services of the Member States responsible for issuing registration certificate vehicles dated December 20, 2006 [27]; Regulation (EC) No. 1987/2006 on the establishment, operation and use of the second generation Schengen information system (SIS II) dated December 20, 2006 [28]; 
Decision of the Commission (EC) 2017/1528, which replaces the Annex to the Implementation Decision 2013/115/EU on the SIRENE Manual and other implementing measures for the second generation of the Schengen Information System (SIS II) dated August 31, 2017 [29].

The conclusions drawn from the results of this study and the following provisions are made possible by the application of a branched system of scientific methods. In particular, the methods of system and structural analysis were widely used. The methods of legal modeling allowed determining the perspective directions of international legal regulation of police cooperation, and the method of formal-logical and axiological analysis revealed the essence and value orientations of the formation of international legal regulation in this area. Besides, the important findings were obtained due to contrasting, comparison and incorporation of international legal acts and methods of international legal relations regulation in the field of cooperation between law enforcement (police) authorities.

\section{RESULTS}

While analyzing an array of international legal acts in the field of cooperation of police agencies, it is expedient to draw a number of conclusions, which incidentally do not verify the hypothesis we propose to unify the legal regulation of the activities of police agencies at the national level.

The first conclusion concerns the direct nature and structure of the international legal regulation. In particular, we mean the possibility of diversifying the relevant international legal acts only on the ground of the regulation level (global vs regional) and the subject of the publication (international organization vs regional organization). In our opinion, the classification of the sectoral features of international legal acts is inappropriate, since the overwhelming majority of them encompass, by their international legal regulation, several areas of cooperation between the police departments of different countries. But considering the classification of international acts in a given area by the level of regulation: global vs regional, we conclude that there are two parallel goals. The first one is to overcome the global challenges and risks that the police have to face and battle. The second goal is to create a transparent security environment at the level of a regional association, an economic union, an association, etc. in order to overcome the spread of criminal influence on public, legal, and socio-economic processes. International cooperation in the field of collaboration between police agencies involves the creation of a specific information and analytical space, which mainly involves the information exchange as well as the analytical and methodological support for the investigation of crimes that violate both international law and the national legislation of the countries taking part in such cooperation. However, as demonstrated by the research of modern experts and specialists in the field of international police cooperation, there is an urgent need to expand the list of regulatory mechanisms and to include those that can provide direct execution of operational searches of foreign police agencies in the territory of the third countries with the participation of police authorities of these countries. In fact, such a model exists within the framework of organizations Interpol and
Europol, but their legal regulation requires clearer and more transparent rules for the organization of interaction with the national police authorities.

On the other hand, considering the international legal regulation when taking into account the system of acts and norms of these organizations, one should speak not about the supranational law and the unification of the national, but rather on the opposite - about the existence of the national legislation in the field of regulating the activities of the police authorities and the system of international acts that would be based on and proceed from the terms of regulation stipulated by the national legislation. From this angle, the structure of the international legal regulation of police cooperation can be represented as follows (Fig. 1).

The essence of the mechanism we propose is that the national legal acts are the starting point for the formation of international legal acts. It is within the framework of regional police cooperation organizations, is transformed into certain unified models and methods of cooperation, which at the global level acquire the characteristics of organizational and legal support.

For example, the national legislation of the EU states determines the procedure for prosecution and the method of organizing the law enforcement intelligence operations. Having united in Europol, and within Interpol, European countries have developed unified approaches to police cooperation, as reflected among other things, in the form of information and analytical and methodological cooperation. Such cooperation is governed by relevant international instruments, in particular Council Decision No. 2007/533/JHA dated June 12, 2007 about the establishment, operation and use of the second generation Schengen Information System (SIS II) [23]; Regulation of the European Parliament and of the European Union Council No. 1987/2006 dated December 20, 2006 on the establishment, operation and use of the second generation Schengen Information System (SIS II) [26], etc.

This approach demonstrates the importance of the legal determination of all the cooperation procedures without any exception and bringing them into line with the requirements of the current national legislation, since criminal prosecution and criminal proceedings are conducted under the national law, and therefore the evidence base is gathered in the process of international police cooperation, and other aspects of the criminal case must comply with the requirements of the national legislation.

This conclusion, in our opinion, reveals such feature of the international legal regulation of police cooperation as the existence as an organizational and methodological provision for the conduct of investigative, intelligence and operational activities in the criminal prosecution, as well an organizational and methodological support for a set of actions on prevention and combating all forms of crime without exception, constituting a regional and global threat. In other words, the nature of international police cooperation can be represented as follows (Fig. 2).

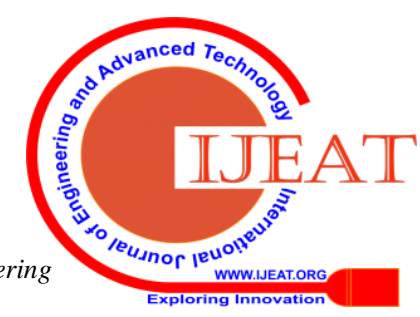




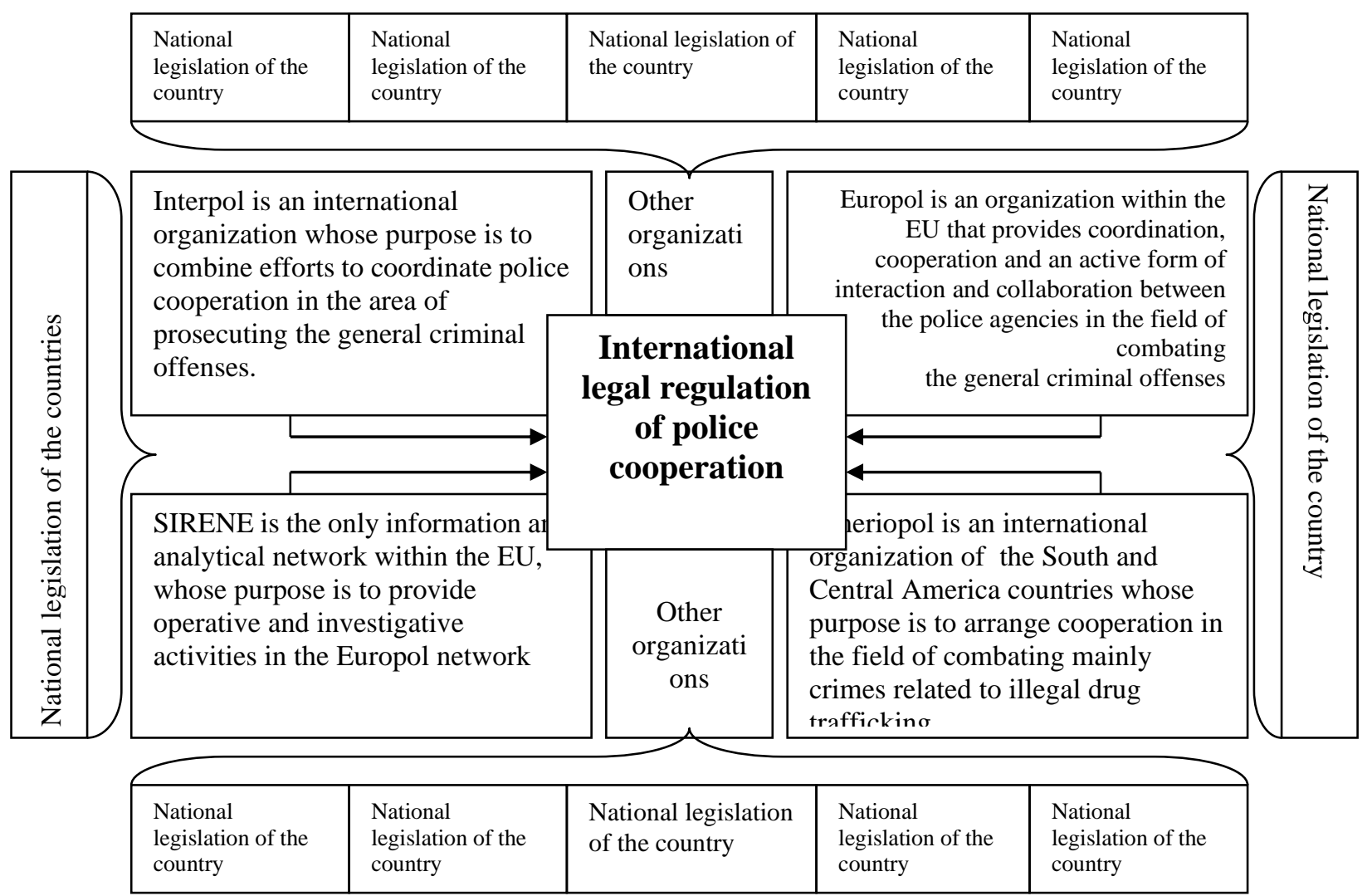

Figure 1. The process structure of the international legal relations regulation in the field of cooperation between law enforcement (police) authorities.

\begin{tabular}{|c|c|c|}
\hline Intelligence & \multirow{3}{*}{$\begin{array}{l}\text { defines the model and } \\
\text { methods of } \\
\text { cooperation, must be } \\
\text { ratified }\end{array}$} & \multirow{3}{*}{$\begin{array}{l}\text { International legal acts in the sphere of } \\
\text { strategic development of socio-economic and } \\
\text { public-political processes, in which the main } \\
\text { risks and threats to global and regional } \\
\text { security are stipulated. }\end{array}$} \\
\hline $\begin{array}{l}\text { Risks identification and } \\
\text { analysis }\end{array}$ & & \\
\hline Target and ranking threats & & \\
\hline $\begin{array}{l}\text { Prevention of threats and } \\
\text { organization of information } \\
\text { exchange }\end{array}$ & \multirow{2}{*}{$\begin{array}{l}\text { regulates the } \\
\text { criminal-procedural } \\
\text { aspects of prosecution }\end{array}$} & \multirow[t]{2}{*}{$\begin{array}{l}\text { National legislation (mainly criminal } \\
\text { procedural), which defines the procedure and } \\
\text { methods of prosecution, the legal mode of } \\
\text { evidence, etc. }\end{array}$} \\
\hline $\begin{array}{l}\text { Investigation and collection } \\
\text { of evidence }\end{array}$ & & \\
\hline
\end{tabular}

Figure 2. The nature and emphasis of interndtional legal relations regulation in the field of cooperation between law enforcement (police) authorities.

Hence, we arrive at the second conclusion: the main emphasis of international legal relations regulation in the field of cooperation between law enforcement (police) authorities should be directed at providing the adequate level of legitimacy to the evidence obtained as a result of such cooperation. This means that the legal field created at the international or even regional level can not intrinsically incorporate the tools and mechanisms of legal regulation regarding the procedure of collection and use of the evidence base. Similarly, international legal acts can not unify the legal mode of the evidence base. On the other hand, they can create the necessary amount of organizational, legal and methodological support for such processes as joint actions; monitoring and crime prevention; information exchange. Whereby under joint actions we mean not the gathering of evidence, but specific police actions in the area of countering and overcoming extremism, terrorism, fundamentalism, etc. 
The body of the above makes it possible to draw the most important conclusion regarding the nature of international legal relations regulation in the field of cooperation between law enforcement (police) authorities. It relates to the subject matter of the methods and content of legal regulation to the administrative law, or namely to its separate special field international police law. This branch of law is not familiar to most countries in the sense that it does not have an independent methodology and tools, as well as an appropriate doctrine and develops as a separate line of international law. Instead, we advocate the view that international police law should have an independent subject and object of regulation and include the following array of methodological tools:

- the administrative law, which defines the nature of the implementation of national state policy in the field of international cooperation of the police agencies, the provision of public administration in the field of police cooperation, the competence of the relevant bodies in their international activities;

- the international law, which defines the content and boundaries of intergovernmental relations, the manner and extent of delegation of powers in the field of police cooperation to international and regional organizations, etc.;

- the criminal and police law, which defines the legal mode of evidence, the main aspects of the criminal proceedings implementation, etc.

\section{DISCUSSION}

The above conclusions are largely reflected in the studies of the leading contemporary experts in the security sector and in the field of police cooperation. But there are points of view that need to be addressed in order to monitor the future practical significance of the results when they are implemented in the practice of international cooperation between the Ministry of Internal Affairs of Ukraine and, in particular, Europol. Thus, in particular authors in [30] make an inference that cooperation between the police authorities of the EU member states takes place due to the recommendations of Europol and their consolidation in the form of the Resolutions and Directives by the EU institutions. In itself, Europol remains an organization that advocates expanding its own competencies and transforming its own bodies into pan-European level police control bodies [30]. Such activity, although entails the human rights violations, still has its positive results, since it simplifies the cooperation to prevent crime, that is, before the actual crimes are committed, stopping them at the stage of premeditating and attempt. The legal mechanism of police cooperation in the $\mathrm{EU}$ is formed at the expense of the legal harmonization of the Europol powers with the national legislation of each state. It is noted that a prerequisite for effective cooperation is clearly allocated and differentiated mandates, recognized by all the parties of the cooperation, as well as the political will of the countries' national governments. But in order to create a strong and lasting cooperation environment, in addition to mutual respect and trust, a clear structure is needed at all levels of the police [31]. However, the intensification of the cross-border movement of goods, labor, financial instruments and vehicles, intensifying economic ties significantly complicate the work of police agencies, which makes it impossible for them to have a clear bureaucratization and a rigid structure, because in this case the element of mobility and responsiveness to crime manifestations will be lost.

In this context, according to [1], the creation of a supranational body or institution is key to ensuring the proper level of mobility of national police units, with their conjoined coordination and cooperation. However, researchers insist that a joint response to transnational crime should be carried out in light of the unshakable adherence to the imperative of national sovereignty [1]. That is why most international organizations in the field of police cooperation: UN Police; International Criminal Court (Investigation Department); Financial Action Task Force on Money Laundering; Europol, etc. - all of them should be aimed at the observance of national sovereignty with the conjoined inclusiveness of the country's police forces from other countries or global police organizations in a security environment.

But in some cases, according to [2], it is impossible to exclude international organizations from the process of combating crime, even at the national level. In particular, these are the activities of Interpol in the field of combating international terrorism [2]. Since the internationalization of crime is expected to continue to gain in the years to come, Interpol will also continue to expand its mission. The wide-ranging multilateral representation of the organization is an important potential asset in tackling crime, but it also puts the organization in confrontation with the existing bilateral cooperation programs and those initiated by the unilateral national governments of individual countries [3]. Authors in [4] also note, that the number of transnational criminal organizations, which constitute one of the greatest threats to the security of mankind, has sharply gained over the years. These illegal organizations use the opportunities created by the global economy, the weak states and developing countries, as well as the high demand for illegal goods and services. The increasing transnational crime has led many countries to cooperate more effectively to tackle crime [4]. That is, it is possible to state that the current level of crime increase corroborates the need to delegate some of the powers in the sphere of national sovereignty to the supranational level in order to create effective mechanisms for ensuring national security. In this context, [6] makes a rather shrewd inference, pointing out that police cooperation has gone through some cycles of evolution, when political motivation encouraging foreign police agencies to exchange information about potential criminals and their activities ranked second, in particular in criminal investigations. The first place in the modern political environment, guided by the need to create a safe society, is the direct field cooperation of police authorities. This is due to the fact that modern policing strategies are aimed at overcoming global terrorist threats [6]. Such goals are strategic, and therefore require constant stable inclusive involvement of the national police forces in international counter-terrorist operations.

For example, [9] argues that national counter-terrorism policies are best achieved through approaches that involve local law enforcement and intelligence organizations in international cooperation. 
That is, international cooperation in one way or another, but requires the addition of local police agencies, which will ensure the appropriate level of competence and efficiency, and the appropriate amount of practical support. A similar point of view, but on the example of countering the manifestations of extremism in Australia are demonstrated by [8]. For example, Bin [11], on the contrary, emphasizes the need for the development of international law enforcement in the field of police cooperation, which means the main focus is laid on intergovernmental ties between national law enforcement authorities and almost entirely concerns cooperation at the state level. In fact, this means that cooperation focuses on law enforcement authorities at the national level, and almost exclusively applies to local or municipal law enforcement authorities [11]. But according to [10], such a conclusion is legitimate only in relation to the definition of general strategic priorities of international cooperation, defining the main threats, their identification and analytical, informational and methodological support for the process of their prevention. Immediate criminal procedure measures are implemented by the local law enforcement authorities [10]. But this point of view is only appropriate in terms of the traditional forms of crime. However, if we take a look at the rapid development of criminal behavior models and the expansion of the tools for committing crimes, we will see as follows. attracting people to extremist organizations. That is why a great deal of attention is paid to the relationship between offline and online environments. The offline environment is only controlled locally by the corresponding police agencies with relevant territorial jurisdiction. As far as the online environment is concerned, its control requires international cooperation [12]. The same conclusions are drawn by [13], where emphasizes the need to strengthen the international cooperation of police agencies for Internet crime and in [16]. demonstrate the growing trends of cybercrime, but the declining response efficiency for these criminal offenses from the national police agencies. In fact, addressing the problem of crime globalization is inconceivable solely by the efforts of the national government or even interstate cooperation. With the express aim for this issue there are global police organizations, such as Interpol.

So, for instance, Interpol, despite its international status, is committed to act in accordance with international legal acts in the field of human rights. Moreover, Article 3 of the Interpol Charter prohibits the interference or activities of a political, military, religious, or racial nature. Their main goals can be defined as follows: ensuring the independence and neutrality of Interpol as an international organization; adhering to and complying with international extradition laws; protection of individuals from persecution [32]. However, author in [17] holds that Interpol should be involved in countering crime only when such crime has a cross-border activity, that is, crimes committed in several countries. From this standpoint, the involvement of Interpol will consist in the methodological provision of a criminal prosecution process in accordance with the national criminal procedural standards [17]. In contrast, in [18] researcher advocates the expansion of the global police cooperation, as it presents the only possible way to overcome the problem of
There is growing concern about the role of the Internet in

terrorism as one of the most advanced types of criminal activity. According to the researcher, the "smart approach" to counter terrorism is a blend of both hard and soft approaches. National governments must adopt strategies to counter terrorism. But the main focus of such a struggle at the national level is the rehabilitation of prisoners and detainees. Instead, an active counteraction to power is possible only with the participation of transnational police forces [18].

Thus, the above shows that the international legal regulation of police cooperation is recognized by many scholars as a necessary means of intensifying relations on the creation and maintenance of a secure environment. At the same time, it has been proved that an array of international legal norms in this area should not pose a risk to the national sovereignty of countries taking part in international police cooperation.

\section{CONCLUSION}

The foregoing enables us to support our findings that the international legal regulation of police cooperation is based on the requirements, provisions and guidelines for the development of the national systems of law and the models of police activity. Therefore, international cooperation in the field of police cooperation involves the information exchange, strengthening the analytical and methodological support for crime prevention, the development of effective indicators of the crime prevention system, and also expands the possibilities of preventing new forms of cross-border crime. This corresponds to the needs of the criminal justice, which takes place under the jurisdiction of the relevant national courts, observing the relevant criminal procedure law, in particular regarding the mode of evidence. But obtaining such evidence and preventing crime occurs within the framework of the worldwide cooperation, but again with the relevant national police authorities of the country in question. In this respect, international organizations such as Interpol, Europol, FATF, etc. play a huge role. Although their activities are significantly restricted by the provisions on national sovereignty, their participation and coordination of efforts by the national police authorities are of paramount importance in view of the constant transformation of the organized crime forms.

\section{REFERENCES}

1. B. Bowling, R. Reiner, and J. Sheptycki, The Politics of the Police Oxford: Oxford University Press, 2019.

2. M. Deflem, and Sh. McDonough, "International Law Enforcement Organizations," in Comparative and International Policing, Justice, and Transnational Crime, S. Kethineni, Ed., Durham, NC: Carolina Academic Press, 2010, pp. 127-148.

3. W. L. Cheah, "Policing Interpol: The commission for the control of Interpol's files and the right to a remedy," International Organizations Law Review, Vol. 7. 2010, pp. 375-404.

4. Í. Çiftçi, and S. Kula, "What is the role of international cooperation in police training: the practices of turkey from global security perspective?" Uluslararası Hakemli Sosyal Bilimler E-Dergisi, 2014 Available: https://dergipark.org.tr/download/article-file/382905

5. T.V. Portnova, "Synthesized nature of fine arts and ballet theater: System analysis of genre development," European Journal of Science and Theology, Vol. 14(5), 2018, pp. 189-200. 
6. N. Gerspacher, "The history of international police cooperation: a 150-year evolution in trends and approaches," Global Crime, Vol. 9, 2008, pp. 169-184.

7. W. A. Jumblatt, "Merits and Limits of Counter-ideological Work Against Terrorism: A Critical Appraisal,” Small Wars \& Insurgencies, Vol. 28(2), 2017, pp. 291-308.

8. S. Harris-Hogan, K. Barrelle, and A. Zammit, "What is countering violent extremism? Exploring CVE policy and practice in Australia," Behavioral Sciences of Terrorism and Political Aggression, Vol. 8(1), 2016, pp. 6-24.

9. E. J. Dahl, "Local approaches to counterterrorism: The New York Police Department model," Journal of Policing, Intelligence and Counter Terrorism, Vol. 9(2), 2014, pp. 81-97.

10. R. Gunaratna, "Intelligence and Counter Terrorism," Journal of Policing, Vol. 6(1), 2011, pp. 65-82.

11. B. Nussbaum, "Protecting Global Cities: New York, London and the Internationalization of Municipal Policing for Counter Terrorism,' Global Crime, Vol. 8(3), 2007, pp. 213-232.

12. D. Smith, and S. Talbot, "How to make enemies and influence people: A Social Influence Model of Violent Extremism (SIM-VE), " Journal of Policing, Intelligence and Counter Terrorism, Vol. 14(2), 2019, pp. 99-114.

13. C. Archetti, "Terrorism, communication and new media: Explaining radicalisation in the digital age," Perspectives on Terrorism, Vol. 9(1) 2015, pp. 49-58.

14. T.V. Portnova, "Choreography sketches as a representational system of dance recording: From M. Petipa to M. Fokine," Indian Journal Of Science And Technology, Vol. 9(29), 2016, pp. 88740. DOI: 10.17485/ijst/2016/v9i29/88740

15. T.V. Portnova, "Practices and Methods for Actualization of the Scientific Information in Art Excursions (Excursions and Cultura Heritage in the Contemporary World," International Journal of Environmental and Science Education, Vol. 11(14), 2016, pp. 6690-6696.

16. P. S. Bayerl, A. Staniforth, B. Akhar, B. Brewster, K. Johnson, "A framework for the investigation and modelling of online racialization and the identification of radicalized individuals," in Emerging trends in ICT security. Emerging trends in computer science and applied computing. Amsterdam: Elsevier, 2014, pp. 539-547.

17. C. O'Reilly, Colonial Policing and the Transnational Legacy: The Global Dynamics of Policing across the Lusophone Community. London: Routledge, 2018.

18. M. Hettiarachchi, "Rehabilitation to deradicalise detainees and inmates: a counter-terrorism strategy," Journal of Policing, Intelligence and Counter Terrorism, Vol. 13, 2018, pp. 267-283.

19. F. Lemieux, "The nature and structure of international police cooperation: an introduction," in International Police Cooperation: Emerging Issues, Theory and Practice. Cullomton, UK: Willan Publishing, 2010, pp. 1-22.

20. Council Decision 2009/371/JHA of 6 April 2009 establishing the European Police Office (EUROPOL). Available: http://eur-lex.europa.eu/legal-content/EN/TXT/?uri=URISERV:j1002 5

21. General Regulations of the International Criminal Police Organization: Interpol. Office of Legal Affairs, 1956.

22. Constitution of the International Criminal Police Organization: Interpol. Office of Legal Affairs, 1956.

23. Council Decision 2008/615/JHA on the stepping up of cross-border cooperation, particularly in combating terrorism and cross-border crime of 23 June $2008 . \quad$ Available: https://eur-lex.europa.eu/legal-content/EN/TXT/HTML/?uri=CELEX: 32008D0615\&rid $=4$

24. Council Decision 2008/616/JHA on the implementation of Decision 2008/615/JHA on the stepping up of cross-border cooperation, particularly in combating terrorism and cross-border crime of 23 June 2008. Available: https://eur-lex.europa.eu/legal-content/EN/TXT/HTML/?uri=CELEX: 32008D0616\&rid=3

25. Council of Europe Committee of Ministers Recommendation No. R(87) 15 to the Member States on regulating the use of personal data in the police sector. Available: https://rm.coe.int/168062dfd4

26. Council Decision No 2007/533/JHA on the establishment, operation and use of the second generation Schengen Information System (SIS II) of 12 June $2007 . \quad$ Available: https://eur-lex.europa.eu/legal-content/EN/ALL/?uri=CELEX:32007 D0533

27. Regulation (EC) No 1986/2006 of the European Parliament and of the Council of 20 December 2006 regarding access to the Second Generation Schengen Information System (SIS II) by the services in the Member States responsible for issuing vehicle registration certificates.
Available:

https://eur-lex.europa.eu/legal-content/EN/ALL/?uri=CELEX:32006R 1986

28. Regulation (EC) No 1987/2006 of the European Parliament and of the Council of 20 December 2006 on the establishment, operation and use of the second generation Schengen Information System (SIS II). Available:

https://eur-lex.europa.eu/legal-content/EN/ALL/?uri=CELEX:32006R 1987

29. Commission Implementing Decision (EU) 2017/1528 replacing the Annex to Implementing Decision 2013/115/EU on the SIRENE Manual and other implementing measures for the second generation Schengen Information System (SIS II) of 31 August 2017. Available: https://eur-lex.europa.eu/legal-content/EN/TXT/?uri=CELEX:32017 D1528

30. M. Petkov, and D. Krastev, Operative mode for police cooperation between the member states of the European Union. Available: http://ijasos.ocerintjournals.org/download/article-file/527711

31. Customs/Police: Cooperation Handbook (CPCH). Interpol, 2018. Available:

https://cites.org/sites/default/files/eng/prog/enforcement/CustomsPoli ceCoopHandbook_EN_LR.pdf

32. Interpol's Rules on the Processing of Data. Office of Legal Affairs, 2011.

Available: https://www.fedpol.admin.ch/dam/data/fedpol/polizeizusammenarbeit /international/interpol/rpd e.pdf
Published By: Blue Eyes Intelligence Engineering \& Sciences Publication 